\title{
Heats of Formation of Some Barium Aluminates
}

\author{
R. B. Peppler and E. S. Newman
}

\begin{abstract}
The heats of solution in $\mathrm{HCl}, 26.61 \mathrm{H}_{2} \mathrm{O}$ of eight compounds in the system $\mathrm{BaO}-\mathrm{Al}_{2} \mathrm{O}_{3}$ $\mathrm{H}_{2} \mathrm{O}$ were determined. From these data and data taken from the literature, the heats of formation of the compounds at $25^{\circ} \mathrm{C}$ were calculated.
\end{abstract}

\section{Introduction}

The hydrated barium aluminates have been studied by several investigators in order to determine their solubility relationships $[1,2,3,4],{ }^{1}$ but there are virtually no thermochemical data available on these compounds. The purpose of the present investigation is to determine the heats of formation of some of the barium aluminates and barium aluminate hydrates by measuring the heats of solution of these compounds in $2.00 \mathrm{~N} \mathrm{HCl}$. The following compounds were studied: $\mathrm{BaO} \cdot \mathrm{Al}_{2} \mathrm{O}_{3}$, $3 \mathrm{BaO} \cdot \mathrm{Al}_{2} \mathrm{O}_{3}, \quad \mathrm{BaO} \cdot \mathrm{Al}_{2} \mathrm{O}_{3} \cdot \mathrm{H}_{2} \mathrm{O}, \quad \mathrm{BaO} \cdot \mathrm{Al}_{2} \mathrm{O}_{3} \cdot 2 \mathrm{H}_{2} \mathrm{O}$, $\mathrm{BaO} . \mathrm{Al}_{2} \mathrm{O}_{3} .4 \mathrm{H}_{2} \mathrm{O}, \mathrm{BaO} . \mathrm{Al}_{2} \mathrm{O}_{3} .7 \mathrm{H}_{2} \mathrm{O}, 2 \mathrm{BaO} \cdot \mathrm{Al}_{2} \mathrm{O}_{3} .5 \mathrm{H}_{2} \mathrm{O}$, and $7 \mathrm{BaO} .6 \mathrm{Al}_{2} \mathrm{O}_{3} .36 \mathrm{H}_{2} \mathrm{O}$.

\section{Experimental Procedure and Results}

\subsection{Preparation of the Compounds}

The two anhydrous barium aluminates were obtained by igniting appropriate mixtures of $\mathrm{BaCO}_{3}$ and $\mathrm{Al}_{2} \mathrm{O}_{3} .3 \mathrm{H}_{2} \mathrm{O}$ (gibbsite) at $1,400^{\circ} \mathrm{C}$ to obtain $\mathrm{BaO} \cdot \mathrm{Al}_{2} \mathrm{O}_{3}$ and at $1,300^{\circ} \mathrm{C}$ to obtain $3 \mathrm{BaO} \cdot \mathrm{Al}_{2} \mathrm{O}_{3}$. The hydrates $\mathrm{BaO} \cdot \mathrm{Al}_{2} \mathrm{O}_{3} \cdot \mathrm{H}_{2} \mathrm{O}$ and $\mathrm{BaO} \cdot \mathrm{Al}_{2} \mathrm{O}_{3} \cdot 2 \mathrm{H}_{2} \mathrm{O}$ were prepared hydrothermally; $\mathrm{BaO} . \mathrm{Al}_{2} \mathrm{O}_{3} \cdot 4 \mathrm{H}_{2} \mathrm{O}$ was prepared by allowing $\mathrm{BaO} \cdot \mathrm{Al}_{2} \mathrm{O}_{3} \cdot 7 \mathrm{H}_{2} \mathrm{O}$ to stand in contact with an aqueous barium aluminate solution; $7 \mathrm{BaO} .6 \mathrm{Al}_{2} \mathrm{O}_{3} .36 \mathrm{H}_{2} \mathrm{O}$ and $\mathrm{BaO} . \mathrm{Al}_{2} \mathrm{O}_{3} .7 \mathrm{H}_{2} \mathrm{O}$ were prepared by precipitation from a supersaturated aqueous solution of $\mathrm{Ba}(\mathrm{OH})_{2}$ and $\mathrm{BaO}_{2} \mathrm{Al}_{2} \mathrm{O}_{3} ;$ and $2 \mathrm{BaO} . \mathrm{Al}_{2} \mathrm{O}_{3} .5 \mathrm{H}_{2} \mathrm{O}$ was prepared by boiling gibbsite in a $\mathrm{Ba}(\mathrm{OH})_{2}$ solution. Full details of the preparation of these compounds have been presented elsewhere $[3,4]$.

The compounds were stored in glass jars for varying lengths of time prior to this investigation. 'The composition of each had been established by chemical analysis and petrographic examination, and it was assumed that no significant changes had occurred. The uncertainty in the composition of the compounds was estimated to be of the order of 1 percent.

\subsection{Heat of Solution of the Compounds}

The heats of solution of 2-gram samples of each compound in 640 grams of $2.00 \mathrm{~N}$ hydrochloric acid were determined in an isothermally jacketed calorimeter [5]. Solution was complete except in the cases of $\mathrm{BaO} \cdot \mathrm{Al}_{2} \mathrm{O}_{3} \cdot \mathrm{H}_{2} \mathrm{O}$ and $\mathrm{BaO} \cdot \mathrm{Al}_{2} \mathrm{O}_{3} \cdot 2 \mathrm{H}_{2} \mathrm{O}$ where about 1 and 0.1 percent, respectively, of insoluble residue remained. An analysis of these residues indicated that they were uncombined gibbsite.

${ }_{1}$ Figures in brackets indicate the literature references at the end of this paper.
They were considered impurities, and the sample weights were corrected accordingly. The initial calorimeter temperature was so chosen in each case that the final temperature would be approximately $25^{\circ} \mathrm{C}$, the temperature of the bath. The heat-ofsolution data (see table 1) are the calculated isothermal heats of solution at $25^{\circ} \mathrm{C}$. It may be noted that the heats of solution per gram of the two anhydrous compounds are higher than that of any of the hydrates, and that in the series $\mathrm{BaO} \cdot \mathrm{Al}_{2} \mathrm{O}_{3} \cdot \mathrm{H}_{2} \mathrm{O}$, $\mathrm{BaO} \cdot \mathrm{Al}_{2} \mathrm{O}_{3} \cdot 2 \mathrm{H}_{2} \mathrm{O}, \mathrm{BaO} \cdot \mathrm{Al}_{2} \mathrm{O}_{3} \cdot 4 \mathrm{H}_{2} \mathrm{O}$, and $\mathrm{BaO} \cdot \mathrm{Al}_{2} \mathrm{O}_{3}$. $7 \mathrm{H}_{2} \mathrm{O}$, the heat of solution decreases as the percentage of combined water in the compound increases.

\section{TABLE 1. Heats of solution and formation of the barium} aluminates

\begin{tabular}{|c|c|c|c|c|}
\hline \multirow{2}{*}{ Compound } & \multicolumn{2}{|c|}{ Heat of solution } & \multicolumn{2}{|c|}{$\begin{array}{c}\text { Heat of formation, } \\
\Delta \mathrm{H}_{f} \text {, at } 25^{\circ} \mathrm{C}-\end{array}$} \\
\hline & $\mathrm{cal} / \mathrm{g}$ & $\mathrm{kcal} / \mathrm{mole}$ & $\begin{array}{c}\text { From the } \\
\text { oxidesa }\end{array}$ & $\begin{array}{l}\text { From the } \\
\text { elements }\end{array}$ \\
\hline $\begin{array}{l}\mathrm{BaO} \\
\mathrm{Al} \mathrm{O}_{3}(\alpha) \\
\mathrm{BaO} \cdot \mathrm{Al}_{2} \mathrm{O}_{3} \\
3 \mathrm{BaO} \cdot \mathrm{Al}_{2} \mathrm{O}_{3} \cdot \mathrm{H}_{2} \mathrm{O} \\
\mathrm{BaO} \cdot \mathrm{Al}_{2} \mathrm{O}_{3} \cdot \mathrm{O}_{2} \\
\mathrm{BaO} \cdot \mathrm{Al}_{2} \mathrm{O}_{3} \cdot 2 \mathrm{H}_{2} \mathrm{O} \\
\mathrm{BaO} \cdot \mathrm{Al}_{2} \mathrm{O}_{3} \cdot 4 \mathrm{H}_{2} \mathrm{O} \\
\mathrm{BaO} . \mathrm{Al}_{2} \mathrm{O}_{3} \cdot 7 \mathrm{H}_{2} \mathrm{O} \\
2 \mathrm{BaO} \cdot \mathrm{Al}_{2} \mathrm{O}_{3} \cdot 5 \mathrm{H}_{2} \mathrm{O} \\
7 \mathrm{BaO} \cdot 6 \mathrm{Al}_{2} \mathrm{O}_{3} \cdot 36 \mathrm{H}_{2} \mathrm{O}\end{array}$ & $\begin{array}{l}\mathrm{b}-419.1 \\
\mathrm{~b}-588.1 \\
\mathrm{c}-393.6 \pm 0.2 \\
-370.6 \pm 0.3 \\
-333.0 \pm 0.1 \\
-300.6 \pm 0.2 \\
-240.0 \pm 0.8 \\
-190.4 \pm 0.2 \\
-219.0 \pm 0.1 \\
-228.4 \pm 0.1\end{array}$ & $\begin{array}{l}\mathrm{b}-64.28 \\
\mathrm{~b}-59.95 \\
-100.5 \\
-208.3 \\
-91.02 \\
-87.57 \\
-78.57 \\
-72.62 \\
-109.2 \\
-533.0\end{array}$ & $\begin{array}{l}\text { kcal/mole } \\
-23.99 \\
-44.96 \\
-32.95 \\
-36.39 \\
-45.36 \\
-51.29 \\
-78.88 \\
-274.60\end{array}$ & $\begin{array}{l}\text { kcal/mole } \\
-133.4 \\
-399.1 \\
-556.5 \\
-844.2 \\
-633.8 \\
-705.5 \\
-851.1 \\
-1062.0 \\
-1086.6 \\
-6062.5\end{array}$ \\
\hline
\end{tabular}

a From $\mathrm{BaO}(\mathrm{c}), \mathrm{Al}_{2} \mathrm{O}_{3}(\mathrm{c}, \boldsymbol{\alpha})$, and $\mathrm{H}_{2} \mathrm{O}$ (1).

b Calculated values.

- Standard deviation $= \pm \sqrt{\frac{\Sigma d^{2}}{N}}$.

\subsection{Heats of Formation}

The heats of formation of these barium aluminates may be calculated from their heats of solution and the heats of solution of $\mathrm{BaO}$ and $\mathrm{Al}_{2} \mathrm{O}_{3}$ in the acid used. The heats of solution of these two oxides in $2.00 \mathrm{~N}$ hydrochloric acid were calculated, because gibbsite dissolves very slowly at $25^{\circ} \mathrm{C}$ and $\mathrm{BaO}$ is difficult to prepare.

Thorvaldsen, Brown, and Peaker [6] calculated the heat of solution of $\mathrm{Al}_{2} \mathrm{O}_{3}$ in $\mathrm{HCl}, 200 \mathrm{H}_{2} \mathrm{O}$. Their method is applied in the present work except that more recent data $[7,8]$ are used. The heat of solution of $\mathrm{Al}_{2} \mathrm{O}_{3}(c, \alpha)$ in $\mathrm{HCl}, 26.61^{2} \mathrm{H}_{2} \mathrm{O}$ is obtained as follows:

2 In the preceding paper in this series [9], the concentration of $2.00 \mathrm{~N} \mathrm{HCl}$ was ${ }^{2}$ In the preceding paper in this series [9], the concentration of $2.00 \mathrm{~N}$ HCl was
given as $\mathrm{HCl}, 26.64 \mathrm{H}_{2} \mathrm{O}$. This value was calculated from the data for the density given as $\mathrm{HCl}, 26.64 \mathrm{H}_{2} \mathrm{O}$. This value was calculated from the data for the density
of aqueous $\mathrm{HCl}$ at $25^{\circ} \mathrm{C}$ taken from the International Critical Tables. A new of aqueous $\mathrm{HCl}$ at $25^{\circ} \mathrm{C}$ taken from the International Critical Tables. A new
calculation using more precise molecular weights gives the concentration as $\mathrm{HCl}, 26.61 \mathrm{H}_{2} \mathrm{O}$, and this new value is used through the present paper. 
$2 \mathrm{Al}(\mathrm{c})+6\left(\mathrm{HCl}, 12.74 \mathrm{H}_{2} \mathrm{O}\right)=2\left(\mathrm{AlCl}_{3}, 38.21 \mathrm{H}_{2} \mathrm{O}\right)+$ $3 \mathrm{H}_{2}(\mathrm{~g}) \quad \Delta H_{1}=-253.67 \mathrm{kcal}[6]$

$$
\begin{gathered}
\mathrm{Al}_{2} \mathrm{O}_{3}(\mathrm{c}, \alpha)=2 \mathrm{Al}(\mathrm{c})+3 / 2 \mathrm{O}_{2}(\mathrm{~g}) \quad \Delta H_{2}= \\
+399.09 \mathrm{kcal}[7] \\
3 \mathrm{H}_{2}(\mathrm{~g})+3 / 2 \mathrm{O}_{2}(\mathrm{~g})=3 \mathrm{H}_{2} \mathrm{O}(\mathrm{l}) \quad \Delta H_{3}= \\
-204.95 \mathrm{kcal}[7] \\
3 \mathrm{H}_{2} \mathrm{O}(\mathrm{l})+2 \mathrm{AlCl}_{3}, \\
\left.39.71 \mathrm{H}_{2} \mathrm{O}\right) \quad \Delta H_{4}=-0.24 \mathrm{H}_{2} \mathrm{O}=2\left(\mathrm{AlCl}_{3},\right.
\end{gathered}
$$

The sum of the above four equations gives eq 5 :

$$
\begin{gathered}
\mathrm{Al}_{2} \mathrm{O}_{3}(\mathrm{c}, \alpha)+6\left(\mathrm{HCl}, 12.74 \mathrm{H}_{2} \mathrm{O}\right)=2\left(\mathrm{AlCl}_{3},\right. \\
\left.39.71 \mathrm{H}_{2} \mathrm{O}\right) \quad \Delta H_{5}=-59.77 \mathrm{kcal}
\end{gathered}
$$

The desired heat of solution, however, is represented by the following equation:

$$
\begin{gathered}
\mathrm{Al}_{2} \mathrm{O}_{3}(\mathrm{c}, \alpha)+6\left(\mathrm{HCl}, 26.61 \mathrm{H}_{2} \mathrm{O}\right)=2\left(\mathrm{AlCl}_{3},\right. \\
\left.81.34 \mathrm{H}_{2} \mathrm{O}\right) \quad \Delta H_{6}=-59.95 \mathrm{kcal}
\end{gathered}
$$

Equation 6 may be obtained by adding to eq 5 the following two equations, which represent the necessary dilutions:

$$
\begin{gathered}
2\left(\mathrm{AlCl}_{3}, 39.71 \mathrm{H}_{2} \mathrm{O}\right)=2\left(\mathrm{AlCl}_{3}, 81.34 \mathrm{H}_{2} \mathrm{O}\right) \\
\Delta H_{7}=-2.96 \mathrm{kcal} \\
6\left(\mathrm{HCl}, 26.61 \mathrm{H}_{2} \mathrm{O}\right)=6\left(\mathrm{HCl}, 12.74 \mathrm{H}_{2} \mathrm{O}\right) \\
\Delta H_{8}=+2.78 \mathrm{kcal}
\end{gathered}
$$

The value of $\Delta H_{4}$ was determined by the authors to be $-0.24 \mathrm{kcal}$; that of $\Delta H_{5}$ is $-59.77 \mathrm{kcal}$, the sum of $\Delta H_{1}, \Delta H_{2}, \Delta H_{3}$, and $\Delta H_{4}$. The value of $\Delta H_{7}$ was found to be $-2.96 \mathrm{kcal}$.

The heat-of-formation data for aqueous $\mathrm{HCl}$ [7] solutions were plotted against the square roots of their corresponding molalities, and from the resulting curve the value of $\Delta H_{8}$ was estimated to be +2.78 kcal. In each case, $\Delta H$ represents the heat effect of the equation as written.

The value of $\Delta H_{6}$, which is the sum of $\Delta H_{5}, \Delta H_{7}$ and $\Delta H_{8}$ was calculated to be $-59.95 \mathrm{kcal}$.

The heat of solution of $\mathrm{BaO}$ in $2.00 \mathrm{~N}$ hydrochloric acid was obtained as follows:

$$
\begin{aligned}
& \mathrm{BaO}(\mathrm{c})+2\left(\mathrm{HCl}, 26.61 \mathrm{H}_{2} \mathrm{O}\right)=\mathrm{BaCl}_{2}, 53.23 \mathrm{H}_{2} \mathrm{O}+ \\
& \mathrm{H}_{2} \mathrm{O}(\mathrm{l}) \quad \Delta H_{9}=-64.28 \mathrm{kcal}
\end{aligned}
$$

$$
\mathrm{BaCl}_{2}, 53.23 \mathrm{H}_{2} \mathrm{O}+\mathrm{H}_{2} \mathrm{O}(\mathrm{l})=\mathrm{BaCl}_{2}, 54.23 \mathrm{H}_{2} \mathrm{O}+\Delta H_{10}
$$

The sum of these equations is

$$
\begin{aligned}
& \mathrm{BaO}(\mathrm{c})+2\left(\mathrm{HCl}, 26.61 \mathrm{H}_{2} \mathrm{O}\right)= \\
& \mathrm{BaCl}_{2}, 54.23 \mathrm{H}_{2} \mathrm{O} \quad \Delta H_{11}=-64.28 \mathrm{kcal}
\end{aligned}
$$

which represents the solution of $\mathrm{BaO}$ in an exactly equivalent amount of $2.00 \mathrm{~N}$ hydrochloric acid. The value of $\Delta H_{9}$ was obtained from heat-of-formation data available in the literature [7]. The value of
$\Delta H_{10}$ was assumed to be negligible; consequently, the value of $\Delta H_{11}$ is the same as that of $\Delta H_{9}$.

When the equations describing the solutions of the compounds are subtracted from the sum of the equations describing the solution of the oxides, equations are obtained from which the heat of reaction of the constituent oxides may be deduced. The heats of formation of the compounds may be calculated from the heats of reaction of their constituent oxides, using their known heats of formation.

The calculation of the heat of formation of $\mathrm{BaO} \cdot \mathrm{Al}_{2} \mathrm{O}_{3}$ is presented in detail to illustrate the method. The three equations that represent the solution of the constituent oxides and the compound are:

$$
\begin{gathered}
\mathrm{BaO}(\mathrm{c})+2\left(\mathrm{HCl}, 26.61 \mathrm{H}_{2} \mathrm{O}\right)=\mathrm{BaCl}_{2}, 54.23 \mathrm{H}_{2} \mathrm{O} \\
\Delta \mathrm{H}_{11}=-64.28 \mathrm{kcal}
\end{gathered}
$$

$$
\begin{gathered}
\mathrm{Al}_{2} \mathrm{O}_{3}(\mathrm{c}, \alpha)+6\left(\mathrm{HCl}, 26.61 \mathrm{H}_{2} \mathrm{O}\right)=2\left(\mathrm{AlCl}_{3}, 81.34 \mathrm{H}_{2} \mathrm{O}\right) \\
\Delta H_{6}=-59.95 \mathrm{kcal}
\end{gathered}
$$

$\mathrm{BaCl}_{2}, 2 \mathrm{AlCl}_{3}, 150.3 \mathrm{HCl}, 4218 \mathrm{H}_{2} \mathrm{O}=\mathrm{BaO} \cdot \mathrm{Al}_{2} \mathrm{O}_{3}(\mathrm{c})+$ $158.3\left(\mathrm{HCl}, 26.61 \mathrm{H}_{2} \mathrm{O}\right) \quad \Delta H_{12}=+100.49 \mathrm{kcal}$

The sum of these three equations is the following equation:

$$
\begin{aligned}
& \mathrm{BaO}(\mathrm{c})+\mathrm{Al}_{2} \mathrm{O}_{3}(\mathrm{c}, \alpha)+\mathrm{BaCl}_{2}, 2 \mathrm{AlCl}_{3}, 150.3 \mathrm{HCl}, \\
& 4218 \mathrm{H}_{2} \mathrm{O}=2\left(\mathrm{AlCl}_{3}, 81.34 \mathrm{H}_{2} \mathrm{O}\right)+ \\
& \mathrm{BaO} \cdot \mathrm{Al}_{2} \mathrm{O}_{3}(\mathrm{c})+150.3\left(\mathrm{HCl}, 26.61 \mathrm{H}_{2} \mathrm{O}\right)+ \\
& \mathrm{BaCl}_{2}, 54.23 \mathrm{H}_{2} \mathrm{O} \quad \Delta H_{13}=-23.74 \mathrm{kcal}
\end{aligned}
$$

It may be seen that eq 13 contains the desired equation, which is

$$
\begin{gathered}
\mathrm{BaO}(\mathrm{c})+\mathrm{Al}_{2} \mathrm{O}_{3}(\mathrm{c}, \alpha)=\mathrm{BaO} \cdot \mathrm{Al}_{2} \mathrm{O}_{3}(\mathrm{c}) \\
\Delta H_{14}=-23.99 \mathrm{kcal}
\end{gathered}
$$

In order to obtain eq 14 from eq 13, the following two equations may be added to eq 13 :

$$
\begin{aligned}
& \begin{array}{l}
150.3\left(\mathrm{HCl}, 26.61 \mathrm{H}_{2} \mathrm{O}\right) \\
150.3 \mathrm{HCl}, 4054 \mathrm{H}_{2} \mathrm{O}
\end{array} \quad \mathrm{BaCl}_{2}, 54.23 \mathrm{H}_{2} \mathrm{O}=\mathrm{BaCl}_{2}, \\
& \Delta H_{15}=+0.072 \mathrm{kcal}
\end{aligned}
$$

$\mathrm{BaCl}_{2}, 150.3 \mathrm{HCl}, 4054 \mathrm{H}_{2} \mathrm{O}+2\left(\mathrm{AlCl}_{3}, 81.34 \mathrm{H}_{2} \mathrm{O}\right)=$

$\mathrm{BaCl}_{2}, 2 \mathrm{AlCl}_{3}, 150.3 \mathrm{HCl}, 4218 \mathrm{H}_{2} \mathrm{O}$

$\Delta H_{16}=+0.175 \mathrm{kcal}$

To calculate $\Delta H_{14}$, it was necessary to determine $\Delta H_{15}$ and $\Delta H_{16}$ experimentally.

The sum of $\Delta H_{13},-\Delta H_{15}$, and $-\Delta H_{16}$ is the desired value of $\Delta H_{14}$. The values of $\Delta H_{6}$ and $\Delta H_{11}$ have been shown to be -59.95 and $-64.28 \mathrm{kcal}$, respectively. The value of $\Delta H_{12}$ was determined by the authors to be $+100.49 \mathrm{kcal}$. The value of $\Delta H_{13}$, the sum of $\Delta H_{6}, \Delta H_{11}$, and $\Delta H_{12}$, was then calculated to be $-23.74 \mathrm{kcal}$. To this was added the values of $\Delta H_{15}$ and $\Delta H_{16}$, determined by the authors to be +0.072 and $+0.175 \mathrm{kcal}$, respectively, to obtain $-23.99 \mathrm{kcal}$, the value of $\Delta H_{14}$.

In an exactly analogous manner, the heat of for- 
mation of $3 \mathrm{BaO} \cdot \mathrm{Al}_{2} \mathrm{O}_{3}$ from its constituent oxides, as represented by eq 17 , may be calculated.

$$
\begin{gathered}
3 \mathrm{BaO}(\mathrm{c})+\mathrm{Al}_{2} \mathrm{O}_{3}(\mathrm{c}, \alpha)=3 \mathrm{BaO} \cdot \mathrm{Al}_{2} \mathrm{O}_{3}(\mathrm{c}) \\
\Delta \mathrm{H}_{17}=-44.05 \mathrm{kcal}
\end{gathered}
$$

The procedure for calculating the heats of formation of the hydrates is the same, except that the water of hydration must be considered. The calculations for $\mathrm{BaO} \cdot \mathrm{Al}_{2} \mathrm{O}_{3} \cdot \mathrm{H}_{2} \mathrm{O}$ are presented in detail to illustrate the method. The equations representing the solution in $2.00 \mathrm{~N}$ hydrochloric acid of the constituent oxides and of the compound are

$$
\begin{gathered}
\mathrm{BaO}(\mathrm{c})+2\left(\mathrm{HCl}, 26.61 \mathrm{H}_{2} \mathrm{O}\right)=\mathrm{BaCl}_{2}, 54.23 \mathrm{H}_{2} \mathrm{O} \\
\Delta H_{6}=-59.95 \mathrm{kcal}
\end{gathered}
$$

$$
\begin{gathered}
\mathrm{Al}_{2} \mathrm{O}_{3}(\mathrm{c}, \alpha)+6\left(\mathrm{HCl}, 26.61 \mathrm{H}_{2} \mathrm{O}\right)=2\left(\mathrm{AlCl}_{3}, 81.34 \mathrm{H}_{2} \mathrm{O}\right) \\
\Delta H_{11}=-64.28 \mathrm{kcal}
\end{gathered}
$$

$\mathrm{BaCl}_{2}, 2 \mathrm{AlCl}_{3}, 161.5 \mathrm{HCl}, 4517 \mathrm{H}_{2} \mathrm{O}=$

$\mathrm{BaO} . \mathrm{Al}_{2} \mathrm{O}_{3} \cdot \mathrm{H}_{2} \mathrm{O}(\mathrm{c})+169.5\left(\mathrm{HCl}, 26.61 \mathrm{H}_{2} \mathrm{O}\right)$

$\Delta H_{18}=+91.02 \mathrm{kcal}$

$\mathrm{H}_{2} \mathrm{O}+\mathrm{BaCl}_{2}, 2 \mathrm{AlCl}_{3}, 161.5 \mathrm{HCl}, 4516 \mathrm{H}_{2} \mathrm{O}=$

$\mathrm{BaCl}_{2}, 2 \mathrm{AlCl}_{3}, 161.5 \mathrm{HCl}, 4517 \mathrm{H}_{2} \mathrm{O}+\Delta H_{19}$

The sum of these four equations may be separated into the following two equations:

$$
\begin{gathered}
\mathrm{BaO}(\mathrm{c})+\mathrm{Al}_{2} \mathrm{C}_{3}(\mathrm{c}, \alpha)+\mathrm{H}_{2} \mathrm{O}(\mathrm{l})=\mathrm{BaO} \cdot \mathrm{Al}_{2} \mathrm{O}_{3} \cdot \mathrm{H}_{2} \mathrm{O}(\mathrm{c}) \\
\Delta H_{20}=-32.95 \mathrm{kcal}
\end{gathered}
$$

and

$\mathrm{BaCl}_{2}, 2 \mathrm{AlCl}_{3}, 161.5 \mathrm{HCl}, 4516 \mathrm{H}_{2} \mathrm{O}=\mathrm{BaCl}_{2}$, $54.23 \mathrm{H}_{2} \mathrm{O}+2\left(\mathrm{AlCl}_{3}, 81.34 \mathrm{H}_{2} \mathrm{O}\right)+161.5(\mathrm{HCl}$, $\left.26.61 \mathrm{H}_{2} \mathrm{O}\right) \quad \Delta H_{21}=-0.262 \mathrm{kcal}$

where eq 20 is the desired equation and eq 21 may be broken down into components whose heat effects may be separately determined as follows:

$$
\begin{gathered}
161.5\left(\mathrm{HCl}, 26.61 \mathrm{H}_{2} \mathrm{O}\right)+\mathrm{BaCl}_{2}, 54.23 \mathrm{H}_{2} \mathrm{O}=\mathrm{BaCl}_{2}, \\
161.5 \mathrm{HCl}, 4298 \mathrm{H}_{2} \mathrm{O} \quad \Delta H_{22}=+0.074 \mathrm{kcal}(22)
\end{gathered}
$$

$\mathrm{BaCl}_{2}, 161.5 \mathrm{HCl}, 4298 \mathrm{H}_{2} \mathrm{O}+2\left(\mathrm{AlCl}_{3}\right.$,

$\left.81.34 \mathrm{H}_{2} \mathrm{O}\right)=\mathrm{BaCl}_{2}, 2 \mathrm{AlCl}_{3}, 161.5 \mathrm{HCl}, 4516 \mathrm{H}_{2} \mathrm{O}$

$\Delta H_{23}=+0.188 \mathrm{kcal}$

The values of $\Delta H_{6}$ and $\Delta H_{11}$ have been shown to be -59.95 and $-64.28 \mathrm{kcal}$, respectively, and the value of $\Delta H_{18}$ was determined experimentally to be $+91.02 \mathrm{kcal}$. An attempt was made to determine the value of $\Delta H_{19}$ experimentally, but its magnitude was so small that it could not be measured with any degree of certainty with the available apparatus, and is therefore assumed to be zero. The sum of $\Delta H_{6}$, $\Delta H_{11}, \Delta H_{18}$, and $\Delta H_{19}$ was then calculated to be $-34.89 \mathrm{kcal}$. The values of $\Delta H_{22}$ and $\Delta H_{23}$ were determined by the authors to be +0.074 and +0.188 kcal, respectively. Adding these to the previous sum gives a value of $-32.95 \mathrm{kcal}$ for $\Delta H_{20}$.

In an analogous manner the heats of formation from their constituent oxides of the other barium aluminate hydrates may be calculated. The corresponding reactions are:

$$
\begin{gathered}
\mathrm{BaO}(\mathrm{c})+\mathrm{Al}_{2} \mathrm{O}_{3}(\mathrm{c}, \alpha)+2 \mathrm{H}_{2} \mathrm{O}(\mathrm{l})=\mathrm{BaO} \cdot \mathrm{Al}_{2} \mathrm{O}_{3} \cdot 2 \mathrm{H}_{2} \mathrm{O}(\mathrm{c}) \\
\Delta H_{24}=-36.39 \mathrm{kcal} \\
\mathrm{BaO}(\mathrm{c})+\mathrm{Al}_{2} \mathrm{O}_{3}(\mathrm{c}, \alpha)+4 \mathrm{H}_{2} \mathrm{O}(\mathrm{l})=\mathrm{BaO} \cdot \mathrm{Al}_{2} \mathrm{O}_{3} \cdot 4 \mathrm{H}_{2} \mathrm{O}(\mathrm{c}) \\
\Delta H_{25}=-45.36 \mathrm{kcal} \\
\mathrm{BaO}(\mathrm{c})+\mathrm{Al}_{2} \mathrm{O}_{3}(\mathrm{c}, \alpha)+7 \mathrm{H}_{2} \mathrm{O}(\mathrm{l})=\mathrm{BaO} . \mathrm{Al}_{2} \mathrm{O}_{3} .7 \mathrm{H}_{2} \mathrm{O}(\mathrm{c}) \\
\Delta H_{26}=-51.29 \mathrm{kcal} \\
2 \mathrm{BaO}(\mathrm{c})+\mathrm{Al}_{2} \mathrm{O}_{3}(\mathrm{c}, \alpha)+5 \mathrm{H}_{2} \mathrm{O}(\mathrm{l})= \\
2 \mathrm{BaO} \cdot \mathrm{Al}_{2} \mathrm{O}_{3} .5 \mathrm{H}_{2} \mathrm{O}(\mathrm{c}) \quad \Delta H_{27}=-78.88 \mathrm{kcal} \\
7 \mathrm{BaO}(\mathrm{c})+6 \mathrm{Al}_{2} \mathrm{O}_{3}(\mathrm{c}, \alpha)+36 \mathrm{H}_{2} \mathrm{O}(\mathrm{l})= \\
7 \mathrm{BaO} .6 \mathrm{Al}_{2} \mathrm{O}_{3} \cdot 36 \mathrm{H}_{2} \mathrm{O}(\mathrm{c}) \quad \Delta H_{28}=-274.60 \mathrm{kcal}
\end{gathered}
$$

\begin{tabular}{|c|c|c|c|}
\hline $\begin{array}{l}\text { Amount of } \\
\mathrm{BaCl}_{2} \\
\text { solution }\end{array}$ & $\begin{array}{c}\text { Weight of } \\
\mathrm{BaCl}_{2}\end{array}$ & $+\Delta H$ & $+\Delta H$ \\
\hline \multicolumn{4}{|c|}{$\begin{array}{l}\text { Varying amounts of a 17.57-percent aqueous solution of } \\
\qquad \mathrm{BaCl}_{2} \text { in } 610 \mathrm{~g} \text { of } 2.00 \mathrm{~N} \mathrm{HCl}\end{array}$} \\
\hline $\begin{array}{l}m l \\
0.562 \\
5.62 \\
8.00 \\
10.73\end{array}$ & $\begin{array}{l}\stackrel{g}{0 .} 1162 \\
\text { 1. } 1616 \\
\text { 1. } 6535 \\
\text { 2. } 2178\end{array}$ & $\begin{array}{l}0.517^{\mathrm{cal} / \mathrm{g}} \\
.415 \text { (avg of } 4) \\
.324 \\
.282(\mathrm{avg} \text { of } 2)\end{array}$ & $\begin{array}{c}\mathrm{kcal} / \mathrm{mole} \\
0.108 \\
.086 \\
.068 \\
.059\end{array}$ \\
\hline \multicolumn{4}{|c|}{$\begin{array}{l}\text { Varying amounts of 8.34-percent aqueous } \mathrm{AlCl}_{3} \text { solution } \\
\text { in } 610 \mathrm{~g} \text { of } 2.00 \mathrm{~N} \mathrm{HCl} \text { and } 8.18 \mathrm{ml} \text { of } 17.57 \text {-percent } \\
\mathrm{BaCl}_{2} \text { aqueous }\end{array}$} \\
\hline $\begin{array}{l}\text { Amount of } \\
\mathrm{AlCl}_{3} \\
\text { solution }\end{array}$ & $\begin{array}{l}\text { Weight of } \\
\mathrm{AlCl}_{3}\end{array}$ & $+\Delta H$ & $+\Delta H$ \\
\hline $\begin{array}{l}m l \\
10.59 \\
23.70\end{array}$ & $\begin{array}{l}g \\
0.9491 \\
2.1234\end{array}$ & $\begin{array}{l}\mathrm{cal} / \mathrm{g} \\
1.08(\text { avg of } 2) \\
0.66(\text { avg of } 2)\end{array}$ & $\begin{array}{l}\mathrm{kcal} / \text { mole } \\
0.144 \\
\quad .088\end{array}$ \\
\hline
\end{tabular}

For each of these compounds, a group of equations was written, and appropriate dilution experiments were performed. This work required some 17 additional equations of the type already shown. These equations differed slightly from those already given because the heats of solution were all determined using 2-gram samples and a fixed amount, $640 \mathrm{~g}$, of $2.00 \mathrm{~N} \mathrm{HCl}$. It was felt that these equations and calculations need not be shown in detail. It was found to be unnecessary to perform each dilution because of the narrow range of the heat effects. Accordingly, the values presented in table 2 were plotted and the desired heats of dilution determined by interpolation.

TABLE 2. Heats of dilution

From the known heats of formation of the constituent oxides, the heats of formation from their constituent elements of these barium aluminates were calculated and are shown in table 1.

The authors' value of the heat of formation of $\mathrm{BaO} \cdot \mathrm{Al}_{2} \mathrm{O}_{3}$ differs widely from that of Avgustinik 
and Mchedlov-Petrossian [11], who calculated their value from the pressure developed by heating an equimolar mixture of $\mathrm{BaSO}_{4}$ and $\mathrm{Al}_{2} \mathrm{O}_{3}$. These investigators, however, did not identify the products of their reaction, and in a subsequent investigation [12] in which one of them analyzed the products formed by igniting $\mathrm{BaSO}_{4}$ and $\mathrm{Al}_{2} \mathrm{O}_{3}$ in the appropriate stoichiometric ratio, he was unable to produce $\mathrm{BaO} \cdot \mathrm{Al}_{2} \mathrm{O}_{3}$.

Grube and Heintz [13] have calculated the heat of formation of $2 \mathrm{BaO} \cdot \mathrm{Al}_{2} \mathrm{O}_{3}$ from $\mathrm{BaO} \cdot \mathrm{Al}_{2} \mathrm{O}_{3}$ and $\mathrm{BaO}$ to be $-2.11 \mathrm{kcal} / \mathrm{mole}$. The existence of $2 \mathrm{BaO} \cdot \mathrm{Al}_{2} \mathrm{O}_{3}$, however, is not accepted by many investigators, and the present authors made no measurements with samples of that stoichiometric composition.

\section{Summary}

The heats of solution in $2.00 \mathrm{~N}$ hydrochloric acid of eight compounds in the system $\mathrm{BaO}-\mathrm{Al}_{2} \mathrm{O}_{3}-\mathrm{H}_{2} \mathrm{O}$ were determined in an isothermally jacketed calorimeter. The heats of solution of two anhydrous compounds were found to be higher than those of the hydrates. In a series of hydrates that differ only in the amount of water of hydration, the heat of solution decreases as the percentage of combined water increases. The heats of formation of these barium aluminates were calculated from their heats of solution, the heats of solution of $\mathrm{BaO}$ and $\mathrm{Al}_{2} \mathrm{O}_{3}$ in the acid used, and from data available in the litera- ture. From the data presented, the heats of hydration of several barium aluminate hydrates may be readily calculated.

The authors gratefully acknowledge the assistance of E. T. Carlson, who prepared the compounds studied in this investigation.

\section{References}

[1] E. Beckmann, J. prakt Chem. [2] 26, 385 to 421,474 to 503 (1882); 27,126 to 152 (1883).

[2] G. Malquori, Gazz. Chim. ital. 56, 51 (1926).

[3] E. T. Carlson and Lansing S. Wells, J. Research NBS 41, 103 (1948) RP1908.

[4] E. T. Carlson, T. J. Chaconas, and L. S. Wells, J. Research NBS 45, 381 (1950) RP2149.

[5] E. S. Newman and L. S. Wells, J. Research NBS 20,825 (1938) RP1107.

[6] T. Thorvaldsen, W. G. Brown, and C. R. Peaker, J. Am. Chem. Soc. 52, 3927 (1930).

[7] F. D. Rossini, Selected values of chemical thermodynamic properties, NBS C500 (1951).

[8] F. E. Young, J. Am. Chem. Soc. 66, 777 (1944).

[9] R. B. Peppler and E. S. Newman, J. Research NBS 46, 121 (1951) RP2183.

[10] F. D. Rossini, BS J. Research 9, 679 (1932) RP499.

[11] A. I. Avgustinik and O. P. Mtchedlov-Petrossian, J. Applied Chem. USSR 20, 584-90 (1947).

[12] G. M. Smirnov and O. P. Mchedlov-Petrossian, Doklvdy Akvd. Nauch. USSR 64, 223-4 (1949).

[13] G. Grube u G. Heintz, Z. Electrochem. 41 (8) 797 (1935)

Washington, May 11, 1951. 